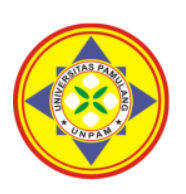

\title{
PENGARUH MOTIVASI DAN DISIPLIN KERJA TERHADAP KINERJA KARYAWAN PADA PT KREASI KEMASAN KOMPOSIT
}

\author{
${ }^{1}$ Lillo Aquilla Bagaskara, ${ }^{2 *}$ Jamaludin \\ Universitas Pamulang, Tangerang, Banten, Indonesia \\ *dosen01020@unpam.ac.id
}

\begin{abstract}
Abstrak
Penelitian ini bertujuan untuk mengetahui pengaruh motivasi dan disiplin kerja terhadap kinerja karyawan pada PT Kreasi Kemasan Komposit, untuk mengetahui bagaimana pengaruh disiplin kerja terhadap kinerja karyawan pada PT Kreasi Kemasan Komposit. Metode yang digunakan pada penelitian ini yaitu metode kuantitatif deskriptif dan asosiatif, yaitu melalui pendekatan, pengumpulan data dan analisa menggunakan statistik. Data yang digunakan melalui teknik observasi, angket (kuesioner sebanyak 63 responden) dan kepustakaan. Metode analisa yang digunakan dalam penelitian ini adalah uji validitas, uji realibilitas, uji normalitas, uji heteroskedastisitas, uji autokorelasi, uji multikolinearitas, uji regresi linear sederhana dan berganda, uji koefisien korelasi, uji determinasi dan uji signifikan (uji t dan uji f).
\end{abstract}

Kata Kunci: Motivasi, Disiplin Kerja dan Kinerja Karyawan.

\section{Abstract}

This study aims to determine the effect of motivation and work discipline on employee performance at PT Kreasi Packaging Komposit, to determine how the effect of work discipline on employee performance at PT Kreasi Packaging Komposit. The method used in this research is descriptive and associative quantitative methods, namely through the approach, data collection and analysis using statistics. The data used through observation techniques, questionnaires (questionnaire as many as 63 respondents) and literature. The analysis method used in this research is validity test, reliability test, normality test, heteroscedasticity test, autocorrelation test, multicollinearity test, simple and multiple linear regression test, correlation coefficient test, determination test and significant test (t test and $f$ test). The significant value of $F$

Keywords: Motivation, Work Discipline and Employee Performance.

\section{PENDAHULUAN}

Keberhasilan suatu perusahaan bisa dipengaruhi kinerja individu karyawannya, didalam perusahaan akan berupaya untuk meningkatkan kinerja karyawan dengan harapan agar tujuan perusahaan dapat tercapai sesuai visi dan misi perusahaan. Kinerja pada dasarnya adalah apa yang dilakukan atau tidak dilakukan karyawan. Tetapi dengan itu perusahaan juga harus memberikan dorongan dan balas jasa yang layak kepada karyawan supaya termotivasi dalam melakukan ataupun menyelesaikan pekerjaan dengan baik dan benar.

Karyawan ialah salah satu faktor penting setiap perusahaan dan merupakan faktor penentu dalam pencapaian tujuan kinerja yang efektif dan efisien, maka dari itu harus selalu ada kesejahteraan karyawan supaya memiliki rasa aman dalam menjalankan tugas dan tanggung jawabnya. Faktor sumber daya manusia ini merupakan elemen yang harus diperhatikan setiap perusahaan karena menyangkut semua segala aspek demi mewujudkan hasil kerja yang produktif dan optimal.

Dari PT Kreasi Kemasan Komposit yang saya teliti ada beberapa bentuk faktor yang sangat jelas dan tidak sesuai memenuhi standar perusahaan untuk meningkatkan kinerja karyawan salah satunya adalah tidak adanya perhatian dalam memberikan arahan dan motivasi terhadap karyawan. Dalam pengelolaan manajamen yang baik dalam lingkungan 
kerja perusahaan dapat mendorong efektivitas kinerja di karenakan pemberian motivasi untuk karyawan merupakan hal yang diperlukan oleh suatu perusahaan guna mendorong efektivitas kinerja karena masih banyak karyawan yang belum mampu memenuhi target tugas yang di berikan perusahaan, sehingga dapat berpengaruh terhadap pencapaian kinerja yang tidak sesuai dengan rencana awal yang di tetapkan.

\section{TINJAUAN PUSTAKA}

1. Motivasi Kerja

Menurut Hasibuan (2017:141)

"Motivasi adalah hal yang menyebabkan, menyalurkan, dan mendukung perilaku manusia, supaya mau bekerja giat dan antusias hasil yang optimal".

Motivasi disini termasuk di dalamnya adalah "Pemberian Kesejahteraan", dimana Kesejahteraan merupakan bentuk pemberian penghasilan baik dalam bentuk materi maupun dalam bentuk non materi, yang diberikan oleh perusahaan kepada pegawai. Dismping itu juga sebagai pemenuhan kebutuhan pegawai oleh perusahaan. Kesejahteraan yang dilaksanakan oleh perusahaan bertujuan untuk memelihara pegawai baik dari segi rohani maupun jasmani guna mempertahankan kinerja dan sikap kerja yang baik di dalam bekerja.

Menurut Hasibuan

"Kesejahteraan dipandang sebagai uang bantuan lebih lanjut kepada pegawai, terutama mereka yang sakit, uang bantuan untuk tabungan pegawai, pembagian berupa saham, asuransi, perawatan rumah sakit, dan dana pensiun."

2. Kedisiplinan

Kedisiplinan merupakan suatu bentuk upaya pegawai yang berusaha memperbaiki dan membentuk pengetahuan, sikap dan perilaku karyawan sehingga perilaku karyawan tersebut secara sukarela berusaha bekerja secara koperatif dengan para karyawan lain serta meningkatkan prestasi kerja. Menurut Sutrisno (2016) mendefinisikan "Kedisiplinan adalah perilaku seseorang yang sesuai dengan peraturan, prosedur kerja yang ada atau sikap dan tingkah laku serta perbuatan yang sesuai dengan peraturan dari organisasi baik tertulis maupun tidak tertulis". Dalam penelitian ini indikator yang digunakan meliputi: taat terhadap aturan waktu taat terhadap aturan organisasi, taat terhadap aturan perilaku dalam pekerjaan, taat terhadap peraturan lainnya.

3. Kinerja Pegawai

Menurut Wibowo (2016:18) mengemukakan "Kinerja merupakan hasil pekerjaan yang mempunyai hubungan kuat strategis organisasi, kepuasan kenosumen dan memberikan kontribusi ekonomi". Sedangkan menurut Ratundo dan Sacket (2016:76) mendefinisikan "Kinerja adalah kegiatan yang mencakup semua tindakan atau perilaku yang dikontrol oleh individu dan memberi kontribusi pada pencapaian tujuan-tujuan perusahaan". Pendapat serupa juga dikemukakan oleh Hariandja (2017:55) yang mengemukakan "Kinerja merupakan hasil kerja yang dihasilkan oleh karyawan atau karyawan atau perilaku nyata

yang ditampilkan sesuai dengan perannya dalam organisasi. Mathis (2016:113) berpendapat "Kinerja adalah apa yang dilakukan atau tidak dilakukan oleh karyawan". Dengan demikian kinerja merupakan proses pencapaian tujuan organisasi dan hasil dari usaha sumber daya manusia itu sendiri dalam sebuah organisasi.

\section{METODE}

Jenis penelitian yang digunakan dalam penelitian ini adalah penelitian kuantitatif deskriptif dan asosiatif

Tempat penelitian dilakukan di PT Kreasi Kemasan Komposit yang berlokasi di Jl. KH. Agus Salim No. 88 Poris Plawad, Kecamatan Cipondoh - Kota Tangerang. 
Waktu penelitian dimulai dari bulan September s/d Desember 2020. Penelitian ini dilakukan secara bertahap dimulai dengan melakukan observasi, penyebaran kuesioner dan mengelola data. Sehingga tercukupi kebutuhan data dan informasi.

Masalah populasi timbul terutama pada penelitian opini yang menggunakan metode survei sebagai teknik pengumpulan data. Adapun populasi dalam penelitian ini adalah karyawan pada PT Kreasi Kemasan Komposit yaitu 63 karyawan.

sampel merupakan bagian dari populasi yang ada, sehingga untuk pengambilan sampel harus menggunakan cara tertentu yang didasarkan oleh pertimbangan-pertimbangan yang ada. Pengambilan sampel dalam penelitian ini dengan teknik sampling karena sampel yang diteliti adalah keseluruhan dari populasi yang ada atau disebut dengan sensus. Mengingat jumlah populasi hanya sebesar 63 karyawan layak untuk diambil keseluruhan tanpa harus mengambil sampel dalam jumlah tertentu. Sehingga sampel dari penelitian ini adalah keseluruhan dari populasi yaitu 63 orang.

\section{HASIL DAN PEMBAHASAN}

1. Uji Hipotesis

Tabel 1. Hasil Uji t

\begin{tabular}{|c|r|r|r|r|r|}
\hline \multirow{2}{*}{ Model } & \multicolumn{2}{|c|}{ Unstandardized Coefficients } & Standardized Coefficients & \multirow{2}{*}{ T } & Sig. \\
\cline { 2 - 6 } & \multicolumn{1}{|c|}{ B } & Std. Error & Beta & 2,406 &, 019 \\
\hline (Constant) & 11,245 & 4,674 &, 290 & 2,175 &, 034 \\
1 Motivasi &, 302 &, 139 &, 389 & 2,916 &, 005 \\
Disiplin Kerja &, 404 &, 139 &, 389 \\
\hline
\end{tabular}

a. Dependent Variable: Kinerja Karyawan

1) Pengaruh Motivasi (X1) Terhadap Kinerja Karyawan $(Y)$ menentukan rumusan hipotesisnya adalah :

Dari tabel diatas diperoleh nilai $t_{\text {hitung }}>t_{\text {tabel }}(2,175>1,671)$ dari nilai signifikan 0,034 $<0,05$ maka dapat disimpulkan $\mathrm{H} 1$ diterima atau variabel Motivasi (X1) secara parsial berpengaruh positif dan signifikan terhadap Kinerja Karyawan (Y).
2) Pengaruh Disiplin Kerja ( $X 2)$ terhadap Kinerja Karyawan (Y) menentukan hipotesisnya adalah : Dari tabel diatas, diperoleh nilai $t_{\text {hitung }}>t_{\text {tabel }}(2,916>1,671)$ dari nilai signifikan 0,005 $<0,05$ maka dapat disimpulkan $\mathrm{H} 2$ diterima atau variabel Disiplin Kerja (X2) secara parsial berpengaruh positif dan signifikan terhadap Kinerja Karyawan (Y).

2. Uji F

Tabel 2. Hasil Pengelolaan Data Pengujian F Simultan

\begin{tabular}{|l|r|r|r|r|r|}
\hline Model & Sum of Squares & Df & Mean Square & F & Sig. \\
\hline \multirow{2}{*}{ Regression } & 225,096 & 2 & 112,548 & 18,564 &, $000^{\mathrm{b}}$ \\
Residual & 363,761 & 60 & 6,063 & & \\
& 588,857 & 62 & & & \\
Total & 58 & & \\
\hline
\end{tabular}

a. Dependent Variable: Kinerja Karyawan

b. Predictors: (Constant), Disiplin Kerja, Motivasi

Berdasarkan hasil pengujian hipotesis yang dilakukan, maka diperoleh kesimpulan sebagai berikut : Hasil Analisis Deskriptif

a. Keadaan atau kriteria objek yang diteliti berdasarkan variabel Motivasi (X1)
Dalam penelitian ini dapat diketahui bahwa Motivasi (X1) mempunyai rata-rata skor jawaban responden 3,86 atau berada pada kategori baik, hal ini menunjukan bahwa Motivasi di PT Kreasi Kemasan Komposit yang dinilai berdaasarkan responden memberikan 
pengaruh terhadap kinerja karyawan itu sendiri. Hal tersebut berpengaruh positif dan signifikan sehingga hipotesis yang di terima. Namun untuk pernyataan indikator tentang kebutuhan fisiologis masih dalam kategori STB.

b. Keadaan atau kriteria objek yang diteliti berdasarkan pada variabel Disiplin Kerja (X2)

Dalam penelitian ini dapat diketahui bahwa Disiplin Kerja (X2) mempunyai rata-rata skor jawaban responden 4,09 atau berada pada BAIK, hal ini menunjukan bahwa disiplin kerja yang diberikan oleh PT Kreasi Kemasan Komposit yang dinilai berdasarkan responden memberikan pengaruh terhadap kinerja karyawan itu sendiri. Hal tersebut berpengaruh positif dan signifikan sehingga hipotesis yang diajukan dapat diterima. Namun untuk pernyataan indikator sanksi hukuman tentang masih dalam kategori KB.

c. Keadaan atau kriterian objek yang diteliti berdasarkan pada variabel Kinerja Karywan (Y)

Dalam penelitian ini dapat diketahui bahwa kinerja karyawan $(\mathrm{Y})$ mempunyai rata-rata skor jawaban responden 4,36 atau berada pada kategori SANGAT BAIK, hal ini menunjukan bahwa kinerja yang diberikan oleh oleh PT Kreasi Kemasan Komposit yang dinilai berdasarkan responden memberikan pengaruh terhadap kinerja karyawan itu sendiri. Hal tersebut berpengaruh positif dan signifikan sehingga hipotesis yang diajukan dapat diterima. Namun untuk pernyataan indikator kerjasama masih dalam katagori KB.

3. Hasil Analisis Verifikatif

Pengaruh Motivasi (X1) Terhadap Kinerja Karyawan $(Y)$

Analisis dari hasil penelitian menunjukan bahwa secara parsial H1 diterima atau variabel Motivasi (X1) mempunyai pengaruh secara positif dan signifikan terhadap variabel Kinerja Karyawan (Y). Dengan demikian apabila semakin baik tingkat motivasi yang di peroleh maka semakin baik meningkat kinerja karyawan. Hasil hipotesis membuktikan motivasi berpengaruh secara positif dan signifikan terhadap kinerja karyawan, dengan di dapat hasil uji $t_{\text {variabel }}$ motivasi dengan membandingkan $t_{\text {hitung }}$ dengan $t_{\text {tabel }}$, $t_{\text {hitung }}>t_{\text {tabel }}(2.175>1,671)$ dengan nilai probabilitas signifikan 0,034 $<0,05$. Adanya angka signifikan pada maka akan meningkatkan kinerja karyawan pada PT Kreasi Kemasan Komposit.

\section{KESIMPULAN}

Berdasarkan hasil analisis penelitian yang telah dilakukan pada PT Kreasi Kemasan Komposit. Maka dapat diambil kesimpulan sebagai berikut:

Analisis dari hasil penelitian menunjukan bahwa secara parsial Ha1 diterima atau variabel Motivasi (X1) mempunyai pengaruh secara positif dan signifikan terhadap variabel Kinerja Karyawan (Y). Hasil hipotesis membuktikan motivasi berpengaruh secara positif dan signifikan terhadap kinerja karyawan, dengan di dapat hasil uji $t_{\text {variabel }}$ motivasi dengan membandingkan $t_{\text {hitung }}$ dengan $t_{\text {tabel }}, t_{\text {hitung }}>t_{\text {tabel }}(2.175>1,671)$ dengan nilai probabilitas signifikan $0,034<$ 0,05.Nilai koefisien Determinasi (R2) sebesar 0,295, yang artinya variabel Motivasi (X1) berpengaruh terhadap variabel Kinerja Karyawan (Y) pada PT Kreasi Kemasan Komposit.

Apabila dari hasil penelitian menunjukan bahwa secara parsial $\mathrm{Ha} 2$ di terima atau variabel Disiplin Kerja (X2) mempunyai pengaruh positif dan signifikan terhadap variabel Kinerja Karyawan (Y). Hasil hipotesis membuktikan bahwa disiplin kerja berpengaruh postitif dan signifikan terhadap kinerja karyawan, dengan di dapat hasil uji $t_{\text {variabel }}$ disiplin kerja dengan membandingkan $t_{\text {hitung }}$ dengan $t_{\text {tabel }}$, 
maka di peroleh $t_{\text {hitung }}(2,916>1,671)$ dengan nilai probabilitas signifikasi 0,005 < 0,05.Nilai koefisien Determinasi sebesar 0,334, yang artinya variabel Disiplin Kerja (X2) berpengaruh terhadap variabel Kinerja Karyawan (Y) pada PT Kreasi Kemasan Komposit.

Apabila dari hasil penelitian menunjukan bahwa secara simultan $\mathrm{Ha} 3$ diterima sehingga terdapat pengaruh positif dan simultan antara motivasi dan disiplin kerja terhadap kinerja karyawan. Hasil hipotesis membuktikan bahwa motivasi dan disiplin kerja berpengaruh postitif dan signifikan terhadap kinerja karyawan, dengan di dapat hasil uji F dengan membandingkan $f_{\text {hitung }}$ dengan $f_{\text {tabel }}$, maka diperoleh $f_{\text {hitung }}=18,564>$ 2,760 atau $\left(f_{\text {hitung }}>f_{\text {tabel }}\right)$ dengan kriteria signifikan $5 \% \quad(0.05)$. Nilai koefisien Determinasi (R2) sebesar 0,382, maka dapat Ha3 disimpulkan bahwa secara simultan Motivasi (X1) dan Disiplin Kerja (X2) berpengaruh terhadap variabel Kinerja Karyawan (Y) sebesar 38,2\% pada PT Kreasi Kemasan Komposit.

\section{DAFTAR PUSTAKA}

A.A Anwar Prabu Mangkunegara. 2011. Manajemen Perusahaan. Bandung. PT.Remaja Rosdakarya. 2013.

AM, E. N., Sarwani, S., Akbar, I. R., Mas' adi, M., \& Maddinsyah, A. Pengaruh Kedisiplinan Dan Pemberian Kesejahteraan Terhadap Kinerja Pegawai Pada Unit Pelaksana Teknis Puskesmas Wilayah Tangerang Selatan. JENIUS (Jurnal Ilmiah Manajemen Sumber Daya Manusia), 4(2), 185-200.

Anoraga, Pandji. 2010. Manajemen Bisnis Edisi Kedua. Jakarta. Rineka.

Arikunto Suharsimi. 2010. Prosedur Penelitian. Jakarta: Rineka Cipta.

Dessler, Gary. 2011. Manajemen Sumber Daya Manusia. Penerbit Indeks, Jakarta.

Dwi,Priyatno. 2014. Mandiri Belajar Analisis Data dengan Spss. Yogyakarta: Mediakom
Edison, Emron. Yohny, Anwar. Imas komariyah.2016. Manajemen Sumber Daya Manusia. Bandung: Alfabeta.

Effendy, A. A., Sunarsi, D., Kristianti, L. S., Irawati, L., \& Wahyitno, W. (2020). Effect Of Giving Reward and Motivation to Employee Productivity In PT. Sinar Kencana Jaya In Surabaya. HUMANIS (Humanities, Management and Science Proceedings), 1(1).

Ghozali, Imam. 2013. Aplikasi Analisis Multivariate dengan Program IBM SPSS 21 Update PLS Regresi. Semarang: Badan Penerbit Universitas Diponegoro.

Ghozali, Imam. 2016. Aplikasi Analisis Multivariete Dengan Program IBM SPSS 23 (Edisi 8). Cetakan ke VIII. Semarang : Badan Penerbit Universitas Diponegoro.

Hartatik, Indah Puji.2014. Buku Praktis Pengembangan Sumber Daya Manusia. Yogjakarta. Laksana.

Hasibuan, Malayu S.P. 2013. Manajemen Sumber Daya Manusia. Jakarta. PT. Bumi Aksara. 2014. Manajemen Sumber Daya Manusia. Jakarta. PT. Bumi Aksara. 2017. Manajemen Sumber Daya Manusia. Jakarta. PT. Bumi Aksara.

Hermawati, Rahmi. (2020). Pengaruh Stres Kerja dan Disiplin Kerja Terhadap Kinerja Karyawan PT Nawakara Arta Kencana Fatmawati Jakarta Selatan. Jurnal Kreatif, 8(1).

Hindriari, Reni. (2018). Pengaruh Pemberian Motivasi dan Disiplin Terhadap Kinerja Karyawan Pada PT Mattel Indonesia. Jurnal Kreatif, 6(1).

Kadarisman, M. 2012. Manajemen Pengembangan Sumber Daya Manusia. Jakarta. Rajawali Pers.

Masram dan Mu'ah. 2017. Manajemen Sumber Daya Manusia. Sidoarjo. Zifatama Publiser.

Mayowan, Yuniadi., M. Djudi,. Chandra Andika, Hadi Purnomo. (2017). Jurnal Administrasi Bisnis (JAB), 48(1). 
Misbahudin, Iqbal Hasan. (2013). Analisis Data Penelitian Dengan Statistik. Jakarta, Bumi Aksara.

Moh Nazir. 2011. Metode Penelitian. Cetakan 6. Bogor. Penerbit: Ghalia Indonesia

Nawawi, 2011. Manajemen Sumber Daya Manusia: Untuk Bisnis Yang Kompetitif. Yogjakarta. Gajahmada University Pers.

Nurjaya, N., Sunarsi, D., Effendy, A. A., Teriyan, A., \& Gunartin, G. (2021). Pengaruh Etos Kerja Dan Disiplin Kerja Terhadap Kinerja Pegawai Pada Dinas Kehutanan Dan Perkebunan Kota Bogor. JENIUS (Jurnal Ilmiah Manajemen Sumber Daya Manusia), 4(2), 172-184.

Nurlaila, 2010. Manajemen Sumber Daya Manusia I. Ternate. Lepkhair.

Prasada, D., Sunarsi, D., \& Teriyan, A. (2020). Pengaruh Etos Kerja Dan Kompensasi Terhadap Komitmen Organisasi Pada DHL Logistic Di Jakarta. JENIUS (Jurnal Ilmiah Manajemen Sumber Daya Manusia), $4(1), 51-60$.

Priyatno, Duwi. 2014. SPSS 22 Pengolahan Data Terpraktis.Yogyakarta: CV Andi Offset.

Rahsel, Yoeyong. (2016). Pengaruh Motivasi Kerja Terhadap Kinerja Pegawai Administrasi Pusat Universitas Padjadjaran Bandung (Studi Pada Bagan Administrasi UNPAD). Jurnal Manajemen Magister, 2(2).

Sarwani, S., Akbar, I. R., Handoko, A. L., \& Ilham, D. (2020). Pengaruh Pelatihan dan Motivasi terhadap Produktivitas Kerja Karyawan pada PT. Lion Mentari Airlines Bandara Internasional Soekarno Hatta Cengkareng. Jurnal Ilmu Komputer dan Bisnis, 11(2a), 91-100.

Setiawan, Kiki Cahaya. (2015). Pengaruh Motivasi Kerja Terhadap Kinerja Karyawan Level Pelaksana Di Divisi Operasi PT Pusri Palembang. Jurnal Psikologi Islami, 1(2).
Siswamto, Bedjo. 2015. Manajemen Tenaga Kerja Indonesia. Bandung. Sinar Baru. Slamet, Afi Rachmat. Djaelani, Abd. Kodir. Ismawati, Ida. (2017). Pengaruh Motivasi dan Disiplin Kerja Terhadap Kinerja Karyawan pada PT Gatra Mapan Ngijo Karangploso Malang. $e^{-}$ Jurnal Riset Manajemen, 6(3).

Sofyan, S., Prasada, D., \& Akbar, I. R. (2020).

Pengaruh Motivasi, Lingkungan

Kerja dan Kepuasan Kerja Terhadap Kinerja Guru SMP/MTs Muhammadiyah Cabang Sawangan. Jurnal Ilmu Komputer dan Bisnis, 11(2a), 33-44.

Standar Nasional Perpustakaan (SNP) Penguruan Tinggi. Perpus RI. 2020

Sudarmanto. 2015. Kinerja dan Pengembangan Kompetensi SDM, edisi tiga. Yogyakarta: Pustaka Pelajar.

Sunarsi, D. (2014). Pengaruh Gaya Kepemimpinan, Motivasi dan Disiplin Kerja Terhadap Kinerja Pendidik (Doctoral dissertation, Universitas Pamulang).

Sunarsi, D. (2016, October). Pengaruh Minat, Motivasi Dan Kecerdasan Kognitif Terhadap Prestasi Belajar (Studi Kasus Pada Mahasiswa Program Studi S-1 Manajemen. Fakultas Ekonomi. Universitas Pamulang. Thn. Akademik 20152016). In Proceedings (Vol. 1, No. 1).

Sutrisno, Edy. 2017. Manajemen Sumber Daya Manusia. Jakarta. Kencana.

Wibowo. 2016. Manajemen Kinerja, Edisi Kelima, PT.Rajagrafindo Persada Jakarta.

Wilandari, D. F., Sunarsi, D., \& Mas'adi, M. (2021). Pengaruh Penilaian Kerja Terhadap Kinerja Karyawan Pada PT. Jaya Mandiri Rekabuana di Cilandak. Jurnal Ekonomi Efektif, 3(2). 